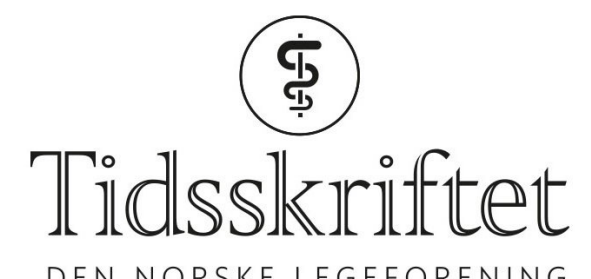

DEN NORSKE LEGEFORENING

\title{
Jobb-hjem-balanse i to kohorter av norske leger
}

ORIGINALARTIKKEL

TUVA KOLSTAD HERTZBERG

E-post: t.k.hertzberg@medisin.uio.no

Allmennlegeklinikken

Drammen

Hun har bidratt med idé, utforming/design, tolking av data, litteratursøk, utarbeiding, revisjon og godkjenning av innsendt manus.

Tuva Kolstad Hertzberg er ph.d. og fastlege.

Forfatteren har fylt ut ICMJE-skjemaet og oppgir ingen interessekonflikter.

\section{REIDAR TYSSEN}

Avdeling for klinisk atferdsvitenskap Institutt for medisinske basalfag

Universitetet i Oslo

Han har bidratt med idé, utforming/design, tolking av data og revisjon og godkjenning av innsendt manus.

Reidar Tyssen er dr.med, spesialist i psykiatri og professor.

Forfatteren har fylt ut ICMJE-skjemaet og oppgir ingen interessekonflikter.

\section{HELGE SKIRBEKK}

Avdeling for helseledelse og helseøkonomi

Institutt for helse og samfunn

Universitetet i Oslo

Han har bidratt med utforming/design og revisjon og godkjenning av innsendt manus.

Helge Skirbekk er ph.d., medisinsk sosiolog og førsteamanuensis.

Forfatteren har fylt ut ICMJE-skjemaet og oppgir ingen interessekonflikter.

\section{KARIN ISAKSSON RØ}

LEFO - Legeforskningsinstituttet

og

Avdeling for medisinsk atferdsvitenskap

Universitetet i Oslo

Hun har bidratt med idé, utforming/design, analyse og tolking av data, litteratursøk, utarbeiding, revisjon og godkjenning av innsendt manus.

Karin Isaksson Rø er ph.d., MHA, spesialist i arbeidsmedisin og instituttleder.

Forfatteren har fylt ut ICMJE-skjemaet og oppgir ingen interessekonflikter.

\section{BAKGRUNN}

Stress knyttet til balansen mellom jobb og hjem, såkalt jobb-hjem-stress, kan påvirke legers helse og livssituasjon. Rapporter har vist økning i stress knyttet til arbeidssituasjon blant norske leger. Vi ville studere utviklingen av denne type stress i perioden 2003-14. 
Jobb-hjem-stress ble målt ved hjelp av tre spørsmål fra validert skala der respondentene anga belastningsnivå fra 1 (ingen belastning) til 5 (svært mye belastning). Målingene ble gjort 10 og 15 år etter studieslutt i to legekohorter, utdannet med seks års mellomrom. Vi brukte t-test og khikvadrattest for å sammenlikne kohortene og kjønn innad i kohortene, og lineær regresjonsanalyse for å justere for eventuelle konfunderende faktorer.

\section{RESULTATER}

Leger utdannet senere (senere kohort, $\mathrm{n}=248$ ) rapporterte signifikant lavere nivå av jobb-hjem-stress ti år etter studiet enn leger som hadde fullført studiene seks år tidligere (tidlig kohort, $\mathrm{n}$ = 197) (gjennomsnittsskår (standardavvik) 2,2 (1,0) vs. 2,6 (1,0), p = o,001). Sammenhengen forble signifikant etter justering for andre forklaringsvariabler, som kjønn (kvinne), antall barn, ukearbeidstid, kollegastøtte og partnerstøtte. 15 år etter studiet var det ingen forskjell på kohortene i opplevd jobb-hjem-stress. Innad i kohortene var det ingen signifikante kjønnsforskjeller ved noe tidspunkt. Etter justering for partnerstøtte og arbeidstid ga det å være kvinne signifikant $ø$ kt risiko for å oppleve jobb-hjem-stress.

\section{FORTOLKNING}

Senere utdannede leger opplevde mindre jobb-hjem-stress ti år etter studiet enn leger utdannet tidligere. Opplevelsen av stress ble bufret hos kvinner som opplevde støtte fra sin partner og hadde redusert arbeidstid.

I 2017 ble legens plikt til å ta vare på egen helse tatt inn i den universelle legeeden (1). $\AA$ ivareta egen helse blir vanskeligere når det oppstår konflikt mellom krav legen har som profesjonell og som privatperson (2-5). I en nyere studie diskuterer man hvordan legers profesjonskultur kan bidra til denne konflikten (6). «Den gode legen» har et sterkt ønske om å fullføre jobbforpliktelsene og beskriver vansker med å balansere dette med ansvaret hjemme. Belastninger på jobben som påvirker hjemmesituasjonen, såkalt jobb-hjem-stress, $\emptyset$ ker risikoen for både utbrenthet, depressive symptomer, dårlig livskvalitet, partnerrelasjonsproblemer og ønske om å bytte jobb (5). Reduksjon av denne type stress har i en norsk studie vist seg som et viktig tiltak for å bedre situasjonen til utbrente leger (7). Funnet støttes av en studie som viste at jobb-hjem-stress har stor betydning for utbrenthetsrisikoen blant norske leger, særlig blant kvinner (8).

Norske leger rapporterer om $\emptyset$ kning i uakseptabelt arbeidspress $(9,10) .40 \%$ opplever stress knyttet til stadige omorganiseringer (10), som fastlegereformen (2001), sykehusreformen (2002), hovedstadsprosjektet (2009) og samhandlingsreformen (2012), i tillegg til lokale omorganiseringsprosesser. Vi ser i økende grad at leger, særlig de unge kvinnelige, søker hjelp på grunn av tung arbeidsbelastning og stort ansvar $(11,12)$.

Bedre jobb-hjem-balanse var et avgjørende tema da sykehuslegene i 2016 streiket. Vedtaket i Arbeidsretten 2017 er sannsynligvis første gang, også internasjonalt, at leger har fått rettslig støtte for betydningen av å ha et privatliv.

I 2018 har vi en overvekt av kvinnelige yrkesaktive leger i Norge, og andelen kvinner øker (13). Når også stadig flere leger har partnere med egne karrierer (14), utfordres jobb-hjembalansen ytterligere for begge kjønn. I Norge finner vi mindre kjønnsforskjeller i jobb-hjem-stress enn de gjør internasjonalt $(15,16)$. Men vi finner kjønnsforskjeller i stresshåndtering: Kvinner reduserte antall arbeidstimer i større grad enn menn (17).

Med en $\emptyset$ kende andel kvinnelige leger, og med stadig flere leger som har partnere som også er i jobb, ønsket vi å studere utviklingen av jobb-hjem-stress. Fordi denne utviklingen også kan påvirkes av faktorer som antall barn, hvor mye legene jobber per uke og sosial støtte fra partner og kolleger, ønsket vi å inkludere disse faktorene. 


\section{Materiale og metode}

NORDOC (The Longitudinal Study of Norwegian Medical Students and Doctors) er en oppfølgingsstudie av to legekohorter, som avsluttet studiene med seks års mellomrom (i 1993/94 og i 1999) og som ble rekruttert fra alle de fire universitetene i Norge med profesjonsstudium (17). Kohortene ble sammenslått $(\mathrm{N}=1052)$ og sammenliknet på fire tidspunkter (ved studieslutt, 4, 10 og 15 år etter studiet). 90 \% (947/1 052) svarte minst én gang og $42 \%$ (450/1 052) svarte ved alle fire tidspunkter.

De aktuelle dataene kommer fra undersøkelser gjort 9-10 år etter studieslutt (data innsamlet i 2003 for den tidlige kohorten og i 2008 for den senere kohorten, $\mathrm{n}=708$, svarprosent 67\%), og 14-15 år etter studieslutt (data innsamlet henholdsvis i 2008 og 2014, n $=598$, svarprosent $57 \%)$.

$M \AA ̊ L$

Effektvariabelen, opplevd jobb-hjem-stress, er en av fire dimensjoner i en tilpasset og validert versjon $(4,17)$ av Cooper's Job Stress Questionnaire (18). Til spørsmålet «I hvilken grad gjør de følgende situasjoner/faktorer deg belastet (stresset)?» har man tre utsagn: Jobben går ut over familielivet / Å få til en balanse mellom arbeid og privatliv / Jobben går ut over sosialt liv. Utsagnene skåres fra 1 (ikke noen belastning) til 5 (svært mye belastning), og gjennomsnitt beregnes.

Vi har benyttet følgende forklaringsvariabler: Alder i år (kontinuerlig), kjønn ( $1=$ kvinne, 2 = mann), sivilstatus ( $1=$ gift eller samboende, $o=$ singel, separert, skilt eller enke/-mann), antall barn (kategorisert fra o-3 eller flere barn, med dummyvariabler hvor det å ha 1-2 barn respektive å ha 3 eller flere barn ble sammenliknet med det å ikke ha barn), antall ukentlige arbeidstimer (inkludert vanlig arbeidstid, selvpålagt og pålagt overtid (kontinuerlig)). Deltidsarbeid ble definert som <37,5 timer/uke. Grunnet høy korrelasjon mellom antall arbeidstimer og deltid ble kun antall arbeidstimer brukt i regresjonsanalysen. Støtte fra kolleger ble målt med gjennomsnitt av spørsmålene «I hvor stor grad har du følt deg ivaretatt av dine kolleger i legegjerningen?» og «I hvilken grad trives du i det store og det hele blant dine kolleger?», der respondentene skåret fra 1 (ikke i det hele tatt) til 7 (svært høy grad) (17). Støtte fra partner ble målt med gjennomsnitt av spørsmålene «Går det dårlig på jobben, finner jeg trøst og støtte hos partner», «Partneren min er fleksibel når det gjelder å gjøre innkjøp, lage middag, hente barn og liknende hvis jeg må jobbe overtid», «Min partner syns jeg jobber for mye» og «Min partner er ofte misfornøyd og sur når jeg jobber for mye overtid» (de to siste er reversert) (17), med skår fra 1 (er ikke tilfelle i det hele tatt) til 5 (er absolutt tilfelle). Legestilling ble kategorisert som $1=$ allmennpraktiker, $2=$ overlege, $3=$ lege i spesialisering (LIS), 4 = andre. I regresjonsanalysen laget vi dummyvariabler hvor hver kategori ble sammenliknet med LIS-leger.

\section{STATISTIKK}

Vi benyttet programvarepakken SPSS Statistics 22 og sammenliknet kontinuerlige data med t-test og kategoriske data med khikvadrattest.

Forklaringsvariabler for opplevd jobb-hjem-stress 10 og 15 år etter studieslutt (kohort, alder, kjønn, sivilstatus, antall barn, stillingskategori, arbeidstid, opplevd kollegastøtte og partnerstøtte) ble unders $\varnothing \mathrm{kt}$ med lineær regresjonsanalyse (tabell 1). I den justerte analysen inkluderte vi kjønn og alder samt alle forklaringsvariablene med $\mathrm{p}<0,10$ i ujusterte analyser. Signifikansnivå ble satt til < 0,05 (tabell 2). For å studere om kjønn og kohorttilhørighet hadde betydning for effektene av de andre variablene, ble det gjort interaksjonsanalyser mellom signifikante variabler og henholdsvis kjønn og kohorttilhørighet. 
Tabell 1

Demografiske data, arbeidstid, jobb-hjem-stress og støtte fra kolleger og partner og type legestilling 10 og 15 år etter endt studium for to kohorter med hhv. 248 og 197 leger. Antall respondenter for de ulike variablene varierer mellom 367 og 445 . Gjennomsnitt (SD) dersom annet ikke er angitt.

\begin{tabular}{|c|c|c|c|c|c|c|}
\hline & \multicolumn{3}{|c|}{10 år etter endt studium } & \multicolumn{3}{|c|}{15 år etter endt studium } \\
\hline & $\begin{array}{l}\text { Tidlig } \\
\text { kohort } \\
(2003)\end{array}$ & $\begin{array}{l}\text { Senere } \\
\text { kohort } \\
(2008)\end{array}$ & $\begin{array}{c}\text { Forskjell, Khi- } \\
\text { kvadrat/t-verdi (p- } \\
\text { verdi) }\end{array}$ & $\begin{array}{c}\text { Tidlig } \\
\text { kohort } \\
(2008)\end{array}$ & $\begin{array}{c}\text { Senere } \\
\text { kohort } \\
(2014)\end{array}$ & $\begin{array}{c}\text { Forskjell, Khi- } \\
\text { kvadrat/t-verdi (p- } \\
\text { verdi) }\end{array}$ \\
\hline $\begin{array}{l}\text { Kjønn, kvinner } \\
(\%)\end{array}$ & 54 & 61 & 0,145 & 54 & 61 & 0,145 \\
\hline Alder i år & $\begin{array}{r}38 \\
(2,9) \\
\end{array}$ & $\begin{array}{r}38 \\
(2,7) \\
\end{array}$ & 0,528 & $\begin{array}{r}43 \\
(2,9) \\
\end{array}$ & $\begin{array}{r}43 \\
(2,7) \\
\end{array}$ & 0,528 \\
\hline Barn (\%) & & & 0,309 & & & 0,075 \\
\hline 0 & 17 & 14 & & 11 & 5 & \\
\hline 1 & 12 & 14 & & 8 & 6 & \\
\hline 2 & 42 & 49 & & 38 & 46 & \\
\hline 3 eller flere & 29 & 23 & & 44 & 43 & \\
\hline $\begin{array}{l}\text { Sivilstatus, har } \\
\text { partner (\%) }\end{array}$ & 85 & 86 & 0,738 & 88 & 89 & 0,636 \\
\hline Timer per uke & $\begin{array}{r}44 \\
(7,7) \\
\end{array}$ & $\begin{array}{r}42 \\
(9,2) \\
\end{array}$ & 0,004 & $\begin{array}{r}42 \\
(10,9) \\
\end{array}$ & $\begin{array}{r}43 \\
(11,7) \\
\end{array}$ & 0,352 \\
\hline Jobber deltid (\%) & 10 & 19 & 0,013 & 23 & 18 & 0,307 \\
\hline $\begin{array}{l}\text { Opplevd } \\
\text { jobb-hjem-stress }\end{array}$ & $\begin{array}{r}2,6 \\
(1,0) \\
\end{array}$ & $\begin{array}{r}2,2 \\
(1,0) \\
\end{array}$ & 0,001 & $\begin{array}{r}2,3 \\
(1,0) \\
\end{array}$ & $\begin{array}{r}2,3 \\
(0,9) \\
\end{array}$ & 0,717 \\
\hline Kollegastøtte & $\begin{array}{r}4,9 \\
(1,2) \\
\end{array}$ & $\begin{array}{r}5,0 \\
(1,1) \\
\end{array}$ & 0,176 & $\begin{array}{r}4,8 \\
(1,2) \\
\end{array}$ & $\begin{array}{r}5,5 \\
(1,2) \\
\end{array}$ & $<0,001$ \\
\hline Partnerstøtte & $\begin{array}{r}3,8 \\
(0,7) \\
\end{array}$ & $\begin{array}{r}3,8 \\
(0,7) \\
\end{array}$ & 0,797 & $\begin{array}{r}3,7 \\
(0,7) \\
\end{array}$ & $\begin{array}{r}3,7 \\
(0,7) \\
\end{array}$ & 0,444 \\
\hline Legestilling (\%) & & & 0,163 & & & 0,774 \\
\hline Fastlege & 17 & 21 & & 19 & 21 & \\
\hline Overlege & 26 & 18 & & 56 & 56 & \\
\hline $\begin{array}{l}\text { Lege i } \\
\text { spesialisering }\end{array}$ & 43 & 49 & & 10 & 11 & \\
\hline Annet & 14 & 11 & & 15 & 12 & \\
\hline
\end{tabular}

\section{Tabell 2}

Kjønnsforskjeller i demografiske data, arbeidstid, jobb-hjem-stress og støtte fra kolleger og partner og type legestilling ti år etter endt studium for to kohorter med hhv. 248 og 197 leger. Gjennomsnitt (SD) dersom annet ikke er angitt.

\begin{tabular}{|c|c|c|c|c|c|c|}
\hline & \multicolumn{3}{|c|}{$\begin{array}{c}\text { Tidlig kohort (10 år etter } \\
\text { studiet) }\end{array}$} & \multicolumn{3}{|c|}{$\begin{array}{c}\text { Senere kohort (10 år etter } \\
\text { studiet) }\end{array}$} \\
\hline & Kvinner & Menn & P-verdi & Kvinner & Menn & P-verdi \\
\hline Alder i år & $38(2,9)$ & $\begin{array}{r}38 \\
(2,7) \\
\end{array}$ & 0,915 & $38(2,4)$ & $\begin{array}{r}38 \\
(2,0) \\
\end{array}$ & 0,816 \\
\hline Barn (\%) & & & 0,335 & & & 0,154 \\
\hline 0 & 21 & 13 & & 14 & 15 & \\
\hline 1 & 10 & 13 & & 17 & 9 & \\
\hline 2 & 43 & 41 & & 43 & 58 & \\
\hline 3 eller flere & 26 & 33 & & 26 & 18 & \\
\hline $\begin{array}{l}\text { Sivilstatus, har } \\
\text { partner (\%) }\end{array}$ & 84 & 88 & 0,357 & 86 & 88 & 0,609 \\
\hline Timer per uke & $43(7,8)$ & $\begin{array}{r}45 \\
(7,5)\end{array}$ & 0,057 & $40(8,5)$ & $\begin{array}{r}44 \\
(9,9)\end{array}$ & 0,017 \\
\hline
\end{tabular}




\begin{tabular}{|c|c|c|c|c|c|c|}
\hline & \multicolumn{3}{|c|}{$\begin{array}{c}\text { Tidlig kohort (10 år etter } \\
\text { studiet) }\end{array}$} & \multicolumn{3}{|c|}{$\begin{array}{c}\text { Senere kohort (10 år etter } \\
\text { studiet) }\end{array}$} \\
\hline & Kvinner & Menn & P-verdi & Kvinner & Menn & P-verdi \\
\hline Jobber deltid (\%) & 12 & 7 & 0,168 & 22 & 13 & 0,124 \\
\hline $\begin{array}{l}\text { Opplevd jobb-hjem- } \\
\text { stress }\end{array}$ & $2,7(1,0)$ & $\begin{array}{r}2,5 \\
(1,0) \\
\end{array}$ & 0,082 & $2,2(0,9)$ & $\begin{array}{r}2,4 \\
(1,0) \\
\end{array}$ & 0,220 \\
\hline Kollegastøtte & $4,9(1,3)$ & $\begin{array}{r}4,8 \\
(1,2)\end{array}$ & 0,548 & $5,1(1,0)$ & $\begin{array}{r}4,9 \\
(1,2)\end{array}$ & 0,387 \\
\hline Partnerstøtte & $3,9(0,6)$ & $\begin{array}{r}3,6 \\
(0,6)\end{array}$ & 0,004 & $3,9(0,6)$ & $\begin{array}{r}3,6 \\
(0,6)\end{array}$ & 0,003 \\
\hline Legestilling (\%) & & & 0,078 & & & 0,002 \\
\hline Fastlege & 18 & 16 & & 18 & 27 & \\
\hline Overlege & 20 & 32 & & 12 & 29 & \\
\hline $\begin{array}{l}\text { Lege i } \\
\text { spesialisering }\end{array}$ & 50 & 36 & & 56 & 38 & \\
\hline Annet & 12 & 16 & & 14 & 6 & \\
\hline
\end{tabular}

I regresjonsanalysene har vi kun inkludert dem som har svart på alle de aktuelle variablene. Antall inkluderte i regresjonsanalysen oppgis i de respektive tabellene.

De som har svart på spørsmålene om jobb-hjem-stress på de to tidspunktene, er i snitt et halvt år yngre enn ikke-respondentene $(\mathrm{p}=0,008)$. Det er ingen statistisk signifikant forskjell i kjønnsfordeling.

\section{ETIKK}

Studien er godkjent av Regional komité for medisinsk og helsefaglig forskningsetikk (REK) sør-øst ( 2010/788a) og av Datatilsynet via Norsk samfunnsvitenskapelig datatjeneste.

\section{Resultater}

\section{STUDIEDELTAKERE}

Til sammen 445 personer ( 248 fra den tidlige kohorten og 197 fra den senere kohorten) besvarte spørsmål om opplevd jobb-hjem-stress ved begge undersøkelsestidspunkter (9-10 og 14-15 år etter studiet).

Det var ingen signifikante forskjeller mellom kohortene i alder, kjønnsfordeling, sivilstatus, antall barn eller type legestilling (tabell 1).

Ti år etter studiet var det signifikant høyere jobb-hjem-stressnivå i den tidlige enn i den senere kohorten, med gjennomsnittsskår 2,6 (SD 1,0) versus 2,2 (SD 1,o), p < o,oo1 (tabell 1), men ingen signifikante forskjeller mellom de to gruppene 15 år etter studiet. Innad i kohortene var det ingen signifikante kjønnsforskjeller i stressnivåer ved noe tidspunkt. Tabell 2 viser sammenligning mellom kjønn i begge kohortene ti år etter studiet. Det var få leger med LIS-stilling i begge kohortene 15 år etter studiet, og kjønnsforskjellene var tilsvarende dem ti år etter studiet (tall ikke vist).

\section{FORKLARINGSVARIABLER}

I den justerte analysen fant vi at det å tilhøre den tidlige kohorten ( $p<0,001)$, å være kvinne $(\mathrm{p}<\mathrm{o}, 001)$, å ha ett eller to barn vs. ingen $(\mathrm{p}=\mathrm{o}, 015)$ eller å ha tre eller flere barn vs. ingen $(\mathrm{p}$ $=0,015)$, ha flere arbeidstimer per uke $(\beta=0,03, \mathrm{p}<0,001)$, oppleve mindre kollegast $\emptyset \mathrm{tte}(\mathrm{p}<$ $\mathrm{o}, 001) \operatorname{og}$ mindre partnerstøtte $(\mathrm{p}<0,001) \emptyset \mathrm{kte}$ sannsynligheten for å oppleve mer jobb-hjem-stress ti år etter studiet. Modellen hadde forklart varians på 34 \% (justert $\mathrm{R}^{2}=$ o,34) (tabell 2). Ujusterte analyser presenteres i tabell 3.

\section{Tabell 3}


Prediktorer for jobb-hjem-stress ti år etter endt medisinstudium $\mathrm{i}$ to kohorter $(\mathrm{n}=338 \mathrm{som}$ svarte på alle variablene). Ujustert og justert lineær regresjon med ustandardiserte $\beta$ - og pverdier.

\begin{tabular}{|c|c|c|c|c|}
\hline & \multicolumn{2}{|l|}{ Ujustert } & \multicolumn{2}{|l|}{ Justert $^{1}$} \\
\hline & $\begin{array}{r}\begin{array}{r}\text { Ustandardisert } \\
\text { beta }\end{array} \\
\end{array}$ & P-verdi & $\begin{array}{r}\text { Ustandardisert } \\
\text { beta }\end{array}$ & P-verdi \\
\hline $\begin{array}{l}\text { Kohort } \\
(0=\text { tidlig kohort, } 1= \\
\text { senere kohort) }\end{array}$ & $-0,39$ & $<0,001$ & $-0,37$ & $\begin{array}{r}p< \\
0,001\end{array}$ \\
\hline $\begin{array}{l}\text { Kjønn } \\
(1=\text { kvinne, } 2=\text { mann })\end{array}$ & $-0,10$ & 0,344 & $-0,44$ & $\begin{array}{r}p< \\
0,001\end{array}$ \\
\hline Alder & 0,02 & 0,436 & 0,005 & 0,763 \\
\hline $\begin{array}{l}\text { Fastlege vs. lege i } \\
\text { spesialisering }\end{array}$ & $-0,01$ & 0,923 & & \\
\hline $\begin{array}{l}\text { Overlege vs. lege i } \\
\text { spesialisering }\end{array}$ & 0,05 & 0,368 & & \\
\hline $\begin{array}{l}\text { Annet vs. lege i } \\
\text { spesialisering }\end{array}$ & $-0,12$ & 0,485 & & \\
\hline $\begin{array}{l}\text { Ett eller to barn vs. } \\
\text { ingen }\end{array}$ & 0,21 & 0,219 & 0,39 & 0,015 \\
\hline $\begin{array}{l}\text { Tre eller flere barn vs. } \\
\text { ingen }\end{array}$ & 0,37 & 0,047 & 0,46 & 0,015 \\
\hline $\begin{array}{l}\text { Sivilstatus }(1=\text { gift } / \\
\text { samboer vs. } 0=\text { singel, } \\
\text { separert, skilt, enke) }\end{array}$ & 0,51 & 0,070 & 0,34 & 0,196 \\
\hline Antall timer/uke & 0,04 & $<0,001$ & 0,03 & $<0,001$ \\
\hline Kollegastøtte & $-0,20$ & $<0,001$ & $-0,15$ & $<0,001$ \\
\hline Partnerstøtte & $-0,68$ & $<0,001$ & $-0,64$ & $<0,001$ \\
\hline
\end{tabular}

${ }^{1}$ Korrigert $\mathrm{R}^{2}=0,34$ for modellen

15 år etter studiet fant vi liknende sammenhenger, bortsett fra at det å ha barn ikke var en signifikant prediktor i den justerte modellen (tabell 4).

\section{Tabell 4}

Prediktorer for jobb-hjem-stress 15 år etter endt medisinstudium i to kohorter ( $\mathrm{n}=327 \mathrm{som}$ svarte på alle variablene). Justert og ujustert lineær regresjon med ustandardiserte $\beta$ - og pverdier.

\begin{tabular}{|c|c|c|c|c|}
\hline & \multicolumn{2}{|l|}{ Ujustert } & \multicolumn{2}{|l|}{ Justert $^{1}$} \\
\hline & $\begin{array}{r}\begin{array}{r}\text { Ustandardisert } \\
\text { beta }\end{array} \\
\end{array}$ & P-verdi & $\begin{array}{r}\begin{array}{r}\text { Ustandardisert } \\
\text { beta }\end{array} \\
\end{array}$ & P-verdi \\
\hline $\begin{array}{l}\text { Kohort } \\
(0=\text { tidlig kohort, } 1= \\
\text { senere kohort) }\end{array}$ & 0,05 & 0,615 & 0,07 & 0,476 \\
\hline $\begin{array}{l}\text { Kjønn } \\
(1=\text { kvinner, } 2=\text { mann })\end{array}$ & $-0,08$ & 0,461 & $-0,33$ & $<0,001$ \\
\hline Alder & $-0,03$ & 0,167 & $-0,03$ & 0,067 \\
\hline $\begin{array}{l}\text { Fastlege vs. lege i } \\
\text { spesialisering }\end{array}$ & $-0,006$ & 0,976 & & \\
\hline $\begin{array}{l}\text { Overlege vs. lege i } \\
\text { spesialisering }\end{array}$ & $-0,062$ & 0,740 & & \\
\hline $\begin{array}{l}\text { Annet vs. lege i } \\
\text { spesialisering }\end{array}$ & $-0,33$ & 0,150 & & \\
\hline $\begin{array}{l}\text { Ett eller to barn vs. } \\
\text { ingen }\end{array}$ & 0,31 & 0,177 & 0,19 & 0,982 \\
\hline
\end{tabular}




\begin{tabular}{|lcccc|}
\hline & $\begin{array}{c}\text { Ujustert } \\
\text { Ustandardisert } \\
\text { beta }\end{array}$ & $\begin{array}{c}\text { P-verdi } \\
\text { Justert }\end{array}$ & $\begin{array}{r}\text { Ustandardisert } \\
\text { beta }\end{array}$ & P-verdi \\
\hline & 0,38 & 0,094 & 0,23 & 0,226 \\
\hline $\begin{array}{l}\text { Tre eller flere barn vs. } \\
\text { ingen }\end{array}$ & 0,09 & 0,740 & & \\
\hline $\begin{array}{l}\text { Sivilstatus (1 = } \\
\text { gift/samboer vs. 0 } \\
\text { singel, separert, skilt, } \\
\text { enke) }\end{array}$ & & & & \\
\hline Antall timer/uke & 0,02 & $<0,001$ & 0,02 & $<0,001$ \\
\hline Kollegastøtte & $-0,19$ & $<0,001$ & $-0,12$ & 0,002 \\
\hline Partnerstøtte & $-0,66$ & $<0,001$ & $-0,57$ & $<0,001$ \\
\hline
\end{tabular}

${ }^{1}$ Korrigert $\mathrm{R}^{2}=0,33$ for modellen

\section{BETYDNINGEN AV KJØNN OG KOHORT}

Ujustert fant vi ikke sammenheng mellom kjønn og jobb-hjem-stress ved noen av måletidspunktene (tabell 3 og 4). Etter justering for partnerstøtte (som kvinner oppgav i større grad enn menn (tabell 2)) og for arbeidstid (som var lavere for kvinner enn for menn (tabell 2)) gav det å være kvinne signifikant $\varnothing$ kt risiko for å oppleve jobb-hjem-stress (tabell 3 og 4). Partnerstøtte og redusert arbeidstid bufret dermed kvinners stressopplevelse.

Det var ingen signifikante interaksjoner mellom kjønn eller kohort og de signifikante prediktorene i de justerte analysene.

\section{Diskusjon}

På tross av rapporter om økning i stressnivåer blant leger (10, 11), blant annet i forbindelse med omorganiseringsprosesser i helsetjenesten (11), finner vi en nedgang i opplevd jobb-hjem-stress ca. ti år etter studiet i den senere kohorten. Ca. 15 år etter studiet finner vi ingen forskjell i kohortene. I motsetning til i internasjonale studier $(15,16)$ rapporterer menn og kvinner i Norge like høye nivåer av jobb-hjem-stress (19). Kvinner rapporterer imidlertid mer partnerstøtte og noe lavere arbeidstid enn menn, og dette viser seg å dempe opplevelsen av stresset blant kvinnene.

Jobb-hjem-stress er vist å øke gjennom de første årene som lege og reduseres i perioden 10-15 år etter studiet $(4,17)$ Dette henger trolig sammen både med endringer i familiesituasjonen (barna blir større) og bedre mulighet for tilpassing av arbeidssituasjon når man blir spesialist og overlege (20). I Norge er det brukt betydelige ressurser på tilrettelegging for foreldre der begge er i arbeid. Det er gode fødselspermisjonsordninger og rett til redusert arbeidstid. Dette kan forklare lavere ukearbeidstid blant leger i den senere kohorten ti år etter studiet. Dessuten $ø$ kte graden av barnehagedekning for $1-5$-åringer fra $62 \%$ til $89 \%$ i perioden $2000-10$ (21).

Ved siden av samfunnsendringene kan en generasjonsendring i profesjonskulturen mot at legeyrket oppleves mer som en jobb enn en livsstil, ha bidratt til at yngre leger setter tydeligere grenser mellom arbeid og privatliv (3, 9). En ny svensk studie viser at muligheten for god jobb-hjem-balanse var viktigere enn lønn både for mannlige og kvinnelige medisinstudenter (22). Den norske sykehuslegestreiken i 2016 tyder også på økt bevissthet om betydningen av denne balansen.

Menn og kvinner står i dag overfor mange av de samme balanseringsutfordringene. Likevel tilpasser kvinnelige leger i den senere kohorten seg hverdagsutfordringene ved å jobbe færre ukearbeidstimer enn sine mannlige kolleger ti år etter studiet. De bruker lengre tid i sine spesialiseringsløp og har trolig i større grad tatt ut foreldrepermisjon og jobbet redusert. Disse forskjellene mellom menn og kvinner fant vi ikke i den tidlige kohorten på tilsvarende tidspunkt. Gitt den økende andelen kvinnelige leger (14) trengs denne kunnskapen på systemnivå, blant annet ved beregning av behov for legestillinger. 
Samtidig trenger helsetjenesten faglig dedikerte leger som er tilpasningsdyktige, ikke minst i omorganiseringsprosesser. Ønske om høy grad av tilstedeværelse på jobb, høye krav til arbeidskapasitet og muligheter for hjemmekontor kan knytte legene tettere til jobben og utfordre jobb-hjem-balansen (9). Leger og arbeidsgivere må ta felles ansvar for å fremme legers helse ved å begrense langvarig stress og legge til rette for en god balanse (9).

\section{STYRKER OG SVAKHETER}

Studiens hovedstyrke er et prospektivt design der man kan sammenlikne legegrupper 10-15 år ut i karrieren med 6-7 års forskyvning, noe som gir mulighet for å unders $ø$ ke endringer over tid.

I denne longitudinelle oppfølgingsstudien av leger var responsratene 9-10 år etter studieslutt og 14-15 år etter studieslutt for begge kohortene samlet henholdsvis $67 \%$ og $57 \%$. I longitudinelle studier synker responsraten oftest med tiden, men er likevel høyere enn responsrater i flere internasjonale tverrsnittsstudier blant leger (23). Basert på få ulikheter mellom deltakerne i NORDOC-studien og studiedeltakerne antar vi at studien er relativt representativ for leger utdannet i Norge i 1990-årene (resultater ikke vist). På grunn av immigrasjon av leger de siste tiårene og nordmenns utenlandsstudier fra 1990-årene er funnene antakeligvis mindre representative for tilsvarende alderskohorter i dag.

\section{Konklusjon}

Studien viser sammenheng mellom mindre jobb-hjem-stress og kortere arbeidstid og at slikt stress for kvinner bufres av opplevd partnerstøtte. Funnene kan tyde på at det særlig for kvinner er blitt noe enklere å sette grenser mellom jobb og privatliv. De norske velferdsgodene med fødselspermisjoner, mulighet for å jobbe redusert og tilnærmet full barnehagedekning styrker slike muligheter.

Fremover trengs det fortsatt $ø$ kt oppmerksomhet på behov i legegruppen og et kollegialt samarbeid for å påvirke at det også på systemnivå tilrettelegges for at jobb-hjem-balanse og egen helse skal kunne ivaretas.

\section{HOVEDBUDSKAP}

Senere utdannede leger (1999) opplevde mindre jobb-hjem-stress ti år etter medisinstudiet enn leger utdannet seks år tidligere (1993/94)

Kortere arbeidstid, færre barn og mer støtte fra kolleger og partner hadde sammenheng med mindre jobb-hjem-stress

\section{LITTERATUR:}

1. Parsa-Parsi RW. The revised declaration of Geneva: A modern-day physician's pledge. JAMA 2017; 318: 1971-2. [PubMed][CrossRef]

2. Greenhaus JH, Beutell NJ. Sources of conflict between work and family roles. Acad Manage Rev 1985; 10: 76-88. [CrossRef]

3. Hertzberg TK, Skirbekk H, Tyssen R et al. Dagens sykehuslege - fremdeles alltid på vakt. Tidsskr Nor Legeforen 2016; 136:1635-8. [PubMed][CrossRef]

4. Hertzberg TK, Rø KI, Vaglum PJ et al. Work-home interface stress: an important predictor of emotional exhaustion 15 years into a medical career. Ind Health 2016; 54: 139-48. [PubMed][CrossRef]

5. Dyrbye LN, Sotile W, Boone S et al. A survey of U.S. physicians and their partners regarding the impact of work-home conflict. J Gen Intern Med 2014; 29: 155-61. [PubMed][CrossRef]

6. Hertzberg TK, Skirbekk H, Tyssen R et al. Den gode legen - sterk og utholdende. Tidsskr Nor Legeforen 2016; 136:1631-4. [PubMed][CrossRef] 
7. Isaksson Rø KE, Tyssen R, Hoffart A et al. A three-year cohort study of the relationships between coping, job stress and burnout after a counselling intervention for help-seeking physicians. BMC Public Health 2010; 10: 213. [PubMed][CrossRef]

8. Langballe EM, Innstrand ST, Aasland OG et al. The predictive value of individual factors, workrelated factors, and work-home interaction on burnout in female and male physicians: a longitudinal study. Stress Health 2011; 27: 73-85. [CrossRef]

9. Aasland OG, Rosta J. Hvordan har overlegene det? Overlegen 2011; 1: 47-55.

10. Aasland OG, Rosta J. Norske leger i spesialisering - hvordan har de det? Forum for yngre leger 2013: 21-3.

11. Isaksson Rø K, Aasland O. Støttelegers syn på støttekollegaordningen. Tidsskr Nor Legeforen 2016; 136: 313-6. [CrossRef]

12. Nilsen L. Psykiater: - Virkeligheten var mye tøffere enn de hadde forestilt seg. Dagens Medisin 5.9.2017. https://www.dagensmedisin.no/artikler/2017/o9/o5/flere-unge-leger-sliter/ Lest 13.3.2018.

13. Den norske legeforening. Legestatistikk.

https://legeforeningen.no/Emner/Andre-emner/Legestatistikk/ Lest 13.3.2018.

14. Rosta J, Isaksson Rø K. Fører gode arbeidsvilkår til at leger får mange barn? Dagens Medisin 22.9.2016.

https://www.dagensmedisin.no/artikler/2016/og/22/forer-gode-arbeidsvilkar-til-at-leger-far-flere-barn/ Lest 13.3.2018.

15. Dyrbye LN, Shanafelt TD, Balch CM et al. Relationship between work-home conflicts and burnout among American surgeons: a comparison by sex. Arch Surg 2011; 146: 211-7. [PubMed][CrossRef]

16. Fuss I, Nübling M, Hasselhorn HM et al. Working conditions and Work-Family Conflict in German hospital physicians: psychosocial and organisational predictors and consequences. BMC Public Health 2008; 8:353. [PubMed][CrossRef]

17. Røvik JO, Tyssen R, Hem E et al. Job stress in young physicians with an emphasis on the work-home interface: a nine-year, nationwide and longitudinal study of its course and predictors. Ind Health 2007; 45: 662-71. [PubMed][CrossRef]

18. Tyssen R, Vaglum P, Gronvold NT et al. The impact of job stress and working conditions on mental health problems among junior house officers. A nationwide Norwegian prospective cohort study. Med Educ 2000;34:374-84. [PubMed][CrossRef]

19. Strand BH, Dalgard OS, Tambs Ket al. Measuring the mental health status of the Norwegian population: a comparison of the instruments SCL-25, SCL-10, SCL-5 and MHI-5 (SF-36). Nord J Psychiatry 2003; 57: 113-8. [PubMed][CrossRef]

20. Solberg IB, Rø KI, Aasland O et al. The impact of change in a doctor's job position: a five-year cohort study of job satisfaction among Norwegian doctors. BMC Health Serv Res 2012; 12: 41.

[PubMed][CrossRef]

21. Statistisk sentralburå. Utdanningsstatistikk. Barnehager 2015, endelige tall.

https://www.ssb.no/utdanning/statistikker/barnehager/aar-endelige/2016-04-20\#content Lest 13.3.2018.

22. Diderichsen S. It's just a job: a new generation of physicians dealing with career and work ideals. Doktoravhandling. Umeå: Umeå university, 2017.

23. Cunningham CT, Quan H, Hemmelgarn B et al. Exploring physician specialist response rates to web-based surveys. BMC Med Res Methodol 2015; 15:32. [PubMed][CrossRef]

Publisert: 24. juni 2019. Tidsskr Nor Legeforen. DOI: 10.4045/tidsskr.18.0339

Mottatt 18.4.2018, første revisjon innsendt 5.10.2018, godkjent 19.3.2019.

(C) Tidsskrift for Den norske legeforening 2020. Lastet ned fra tidsskriftet.no 